\title{
Spatial and temporal variations in the diet of the mysid Mesopodopsis africana in the St. Lucia Estuary (South Africa)
}

\author{
Nicola K. Carrasco*, Renzo Perissinotto \\ School of Biological and Conservation Sciences, University of KwaZulu-Natal, Westville Campus, Durban 4000, \\ P. Bag X 5 4001, South Africa
}

\begin{abstract}
This study presents one of the few known examples where a mysid species has been observed modifying its diet rapidly and under natural conditions in response to environmental changes. Mesopodopsis africana is a dominant mysid in many estuaries along the east coast of South Africa, and a key species in the St. Lucia Estuary, Africa's largest estuarine lake. St. Lucia is currently undergoing severe desiccation owing to freshwater deprivation. Lack of freshwater input has dampened the effect of temporal variations, while different regions have become more spatially heterogeneous. The mixed model SIAR v 4.0 (stable isotope analysis in R) was used to determine the likely contribution of each of the available carbon sources to the diet of $M$. africana. The copepod Pseudodiaptomus stuhlmanni made a significant contribution to $M$. africana's diet in the Mouth region. At Catalina Bay, mysids mostly utilized particulate organic matter (POM), while at Charters Creek they were most closely associated with the macroalga Cladophora sp. The sensitivity of Charters Creek to drought effects is emphasized here, as well as the important role $M$. africana plays in this habitat as an omnivore, increasing the connectance and, hence, sustaining its food web. While the Mouth and Narrows are partly protected from drought effects, the northern lakes have experienced further increases in salinity during the past decade, forcing the periodical exclusion of this mysid from much of the system. This has lead to severe effects on the food webs that the mysid supports under normal conditions.
\end{abstract}

KEY WORDS: Stable isotopes - South Africa - iSimangaliso Wetland Park • Trophic relations · Key species Resale or republication not permitted without written consent of the publisher

\section{INTRODUCTION}

Mysid shrimps are a common and key constituent of estuarine ecosystems, playing an important role in food webs as both consumers and producers (Mauchline 1980). As consumers, mysids are generally considered omnivorous, feeding on a wide range of items. Diet may include phytobenthos, phytoplankton, detritus, sediment, microzooplankton, mesozooplankton, and small benthic invertebrates (Wilhelm et al. 2002, Kibirige \& Perissinotto 2003, Lehtiniemi \& Nordström 2008, Vilas et al. 2008). The ability of mysids to feed selectively on prey of different sizes can modify the structure of estuarine zooplankton (Fulton 1982, Hansson et al. 1990, Kouassi et al. 2006) and phytoplankton
(Lindén \& Kuosa 2004) assemblages. The potential for omnivory allows mysids to modify their diet in response to changes in food quality and abundance (Hughes 1980). Mysids are also relatively adaptive species, capable of enduring the rapid and intense fluctuations in physico-chemical factors often associated with estuarine ecosystems.

The St. Lucia Estuary, Africa's largest estuarine lake, forms part of the iSimangaliso (former Greater St. Lucia) Wetland Park (Fielding et al. 1991, Cyrus \& Vivier 2006). iSimangaliso is South Africa's first World Heritage Site and has been designated a Ramsar Wetland of International Importance (Begg 1978). The St. Lucia Estuary is currently undergoing unusually harsh conditions. The area characteristically experi- 
ences cyclical wet and dry phases, each lasting between 4 and $10 \mathrm{yr}$ (Begg 1978). Past agricultural practices, combined with the below-average rainfall the area has received since 2002, have resulted in the estuary being cut off from the ocean. Low freshwater input and high evaporation rates have led to the persistence of a reversed salinity gradient, with hypersaline conditions in the upper reaches. These harsh conditions combined with the closed-mouth state, have resulted in only the most adaptive species remaining (Carrasco et al. 2010). Dominant zooplankton within the St. Lucia Estuary include the mysid Mesopodopsis africana and the calanoid copepods Pseudodiaptomus stuhlmanni and Acartia natalensis. While the copepods are numerically dominant, mysids tend to be more important in terms of biomass (Wooldridge 1999). Due to the ongoing drought, $M$. africana has disappeared from large sections of the estuarine lake, currently occurring only in its mouth region and in parts of the Narrows and South Lake (Fig. 1).

The present study examines the implications of harsh environmental conditions on the key zooplankton species Mesopodopsis africana. Knowledge of food web properties, such as trophic processes, enables

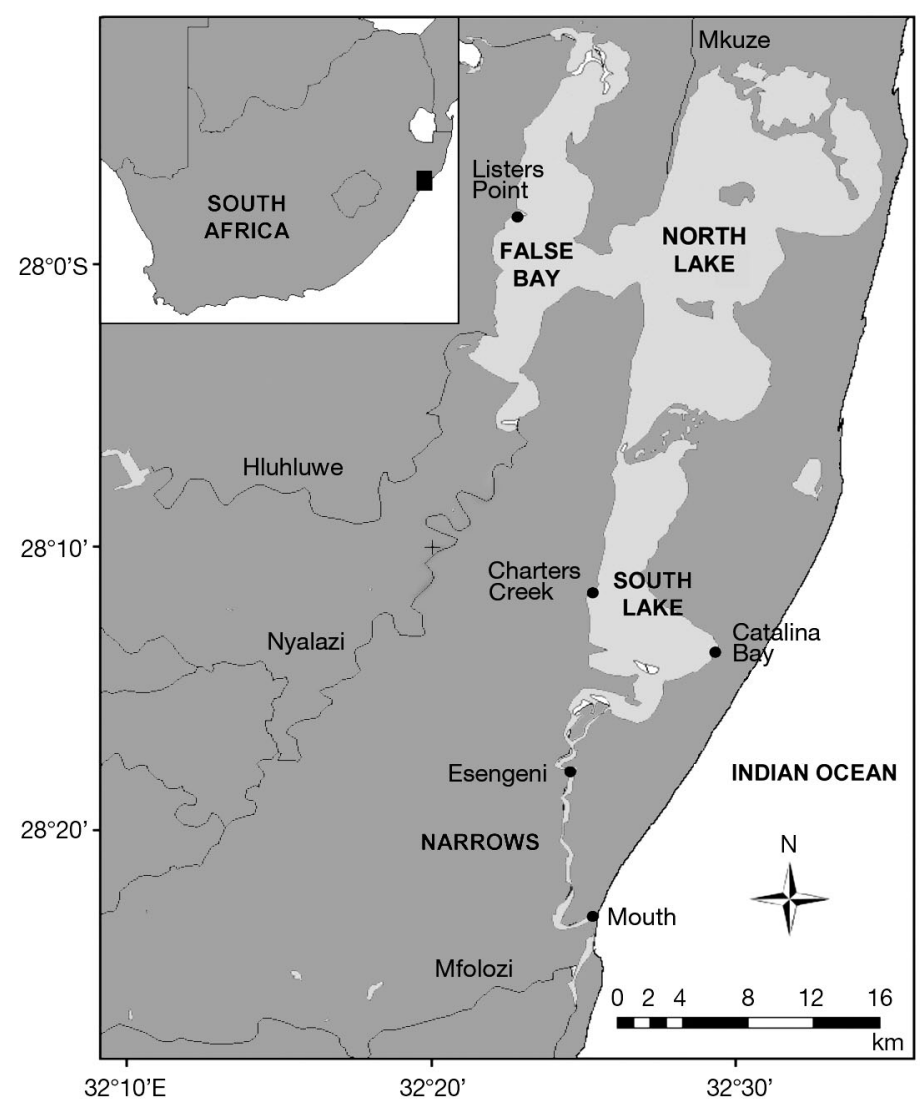

Fig. 1. St. Lucia Estuary. Geographic location within South Africa and the station positions inferences to be made about species interactions and ecosystem structure and function. The use of stable isotopes in ecological research has been recognized as an important tool towards this end. Since stable carbon isotopes $\left(\delta^{13} \mathrm{C}\right)$ are known to fractionate little between energy transfers, they are commonly used to quantify food sources and energy flow in aquatic systems. Stable nitrogen isotopes $\left(\delta^{15} \mathrm{~N}\right)$ fractionate more and are typically used to infer trophic positions of consumers in a food chain (DeNiro \& Epstein 1978, Peterson \& Fry 1987). Models may allow simulation of possible diets and assessment of the relative importance of various sets of organic matter sources to consumers (Phillips \& Eldridge 2006). Knowledge of trophic linkages would be especially relevant information for management, since certain food chain links may disappear due to environmental stresses, such as those currently experienced in the St. Lucia Estuary.

In the subtropical climate of KwaZulu-Natal there are essentially 2 seasons, one characterized by regular rainfall (October-April) and the other with virtually no rain at all (May-September). The current drought crisis has also fractionated the system into very diverse habitats in relatively close range to one another. The overarching aim of this study is, therefore, to assess the spatial and temporal feeding preferences of this key zooplankton species under different environmental conditions. Stable $\delta^{13} \mathrm{C}$ and $\delta^{15} \mathrm{~N}$ isotopes are thus used to gain insight into the trophic interactions and diet of Mesopodopsis africana within the St. Lucia Estuary.

\section{MATERIALS AND METHODS}

Physico-chemical environment and micro-algal biomass. Physico-chemical measurements were taken on each sampling occasion with a YSI 6920 water quality logger fitted with temperature, depth, conductivity, dissolved oxygen, $\mathrm{pH}$ and turbidity probes. For phytoplankton biomass, subsurface water samples were collected from each sampling station and filtered through a GF/F filter to determine the total concentration of chlorophyll $a$ and phaeopigments. Phytoplankton biomass was determined fluorometrically (Turner Designs 10-AU) after cold extracting chl $a$ and phaeopigments from filters in $10 \mathrm{ml} 90 \%$ acetone, for $48 \mathrm{~h}$ in the dark. Microphytobenthic cores $(2 \mathrm{~cm}$ internal diameter, $\mathrm{n}=$ 3 , depth $=1 \mathrm{~cm}$ ) were collected at each station and placed in $100 \mathrm{ml}$ polyethylene bottles containing $30 \mathrm{ml}$ $90 \%$ acetone for chl a extraction (Nozais et al. 2001). Biomass was again determined fluorometrically and expressed as $\mathrm{mg}$ chl $a \mathrm{~m}^{-2}$.

Sample collection and processing. For stable isotope analysis, microphytobenthic biomass (MPB), particulate organic matter (POM), macroalgae (Cladophora 
sp.), detritus, sedimentary organic matter (SOM), and zooplankton samples were collected from stations within the St. Lucia Estuary, depending on their availability. For temporal comparisons, samples were collected from Charters Creek in September 2008 (late winter, dry season) and April 2009 (early autumn, wet season). The latter was used as a wet season comparison, since mysids were not available at Charters Creek until that time. Further samples were collected from the Mouth in February 2009 (summer, wet season) and June 2009 (winter, dry season). In addition, mysids and their potential dietary items were collected simultaneously from 4 different stations within the estuary: the Mouth, Esengeni (the representative station of the Narrows), Catalina Bay, and Charters Creek (Fig. 1) in April 2009, to explore the possibility of spatial differences in the proportion of different carbon (C) sources contributing to the diet of Mesopodopsis africana. The spatial extent of each station was roughly $100 \mathrm{~m}^{2}$ and took about $1 \mathrm{~d}$ to sample.

To obtain an estimate of SOM, the upper $1 \mathrm{~cm}$ layer of sediment was collected and treated with excess $2 \%$ hydrochloric acid $(\mathrm{HCl})$ in order to remove carbonates. The sediment was then rinsed thoroughly with distilled water, dried in an oven at $60^{\circ} \mathrm{C}$ for $24 \mathrm{~h}$, and subsequently crushed with a pestle and mortar (e.g. Smit et al. 2005). Because the amount of SOM material required by the laboratory varied from sample to sample according to the organic content of each sediment type, the SOM material was packaged in micro-centrifuge tubes (Eppendorf), allowing sufficient material to be sent for each sample. The laboratory in Cape Town was then able to withdraw from each tube the correct amount for each sample. Detritus (or decomposing plant organic matter) was collected within the floating foam that was often found at the surface near the water's edge. Detritus was similarly treated with $2 \% \mathrm{HCl}$ to remove biogenic carbonates, rinsed with distilled water, dried at $60^{\circ} \mathrm{C}$ for $24 \mathrm{~h}$, and subsequently crushed with a pestle and mortar and packaged in tin capsules for isotope analysis. Triplicate samples were taken for both SOM and detritus on each sampling occasion.

For the extraction of MPB, dense algal mats were collected by scraping the upper $1 \mathrm{~cm}$ of sediment. This sediment was then re-suspended in filtered estuarine water and stirred, so that the MPB remained in suspension while the heavier sediment settled to the bottom of the container. For stations where the sediment was too fine for this protocol to be used, a procedure similar to that of Couch (1989) was employed. Sediment was collected as above by scraping the upper $2 \mathrm{~mm}$ in areas of dense microalgal mats. Within $4 \mathrm{~h}$, the sediment was brought back to the laboratory where it was spread out onto trays with a depth of about $1 \mathrm{~cm}$. A $63 \mu \mathrm{m}$ nylon sheet was then placed over this, followed by a further nylon sheet. This was then covered with a thin layer of pre-combusted sediment $\left(400^{\circ} \mathrm{C}, 6 \mathrm{~h}\right)$. The trays were held under light, and the sediment was kept moist by spraying it with filtered estuarine water from the sampling site. After $12 \mathrm{~h}$, the top $2 \mathrm{~mm}$ of the sediment into which the motile algae had migrated, was collected and sieved through a $100 \mu \mathrm{m}$ mesh so as to retain the sediment. The microalgae were then filtered onto previously combusted Whatman GF/F filters.

Water samples for POM were filtered onto pre-combusted $\left(450^{\circ} \mathrm{C}, 6 \mathrm{~h}\right)$ Whatman GF/F filters. POM and MPB samples were acid-treated with $2 \% \mathrm{HCl}$ to remove any inorganic carbon in the form of calcium carbonate $\left(\mathrm{CaCO}_{3}\right)$ that may have been present. Filters containing POM and MPB (in triplicate) were placed into aluminium foil envelopes and frozen prior to laboratory-based processing.

Samples of the dominant macroalgae (Cladophora sp.) were collected and rinsed thoroughly with distilled water to ensure the removal of any attached sediment particles. The alga was subsequently dried at $60^{\circ} \mathrm{C}$ in an air-circulated oven for $24 \mathrm{~h}$ and thereafter homogenized into a fine powder using pestle and mortar. Approximately $1 \mathrm{mg}$ of tissue was then placed into 3-5 replicate tin capsules for isotope analysis.

An epibenthic sled was used for the collection of zooplankton (200 $\mu \mathrm{m}$ mesh). While Mesopodopsis africana does undergo diel vertical migration, the water depth at most stations was $<0.5 \mathrm{~m}$. Thus, sampling with the epibenthic sled (radius $=18.5 \mathrm{~cm}$ ) would have resulted in the filtration of almost the entire water column. Where water depth exceeded $1 \mathrm{~m}$ (i.e. Mouth and Esengeni), the use of the hyperbenthic sled would have ensured the suitable collection of epibenthic mysids during the daytime (cf. Kibirige et al. 2006). Zooplankton was concentrated on $200 \mu \mathrm{m}$ Nitex mesh, placed in aluminium foil envelopes, and frozen prior to laboratory sorting into the dominant taxa. These were $M$. africana (Mysidiacea), Pseudodiaptomus stuhlmanni, and Acartia natalensis (Copepoda). Due to the size of these taxa, whole animals needed to be pooled together in order to get enough tissue. About 20 and 200 individuals were needed for each sample for the mysids and copepods, respectively. Three to 5 replicates were used for each species. Zooplankton was first defatted in a solution of methanol:chloroform:distilled water (2:1:0.8; Bligh \& Dyer 1959), before being acid treated $(2 \% \mathrm{HCl})$ to remove $\mathrm{CaCO}_{3}$. After being treated for lipids and carbonates, zooplankton samples were dried in an air-circulated oven at $60^{\circ} \mathrm{C}$ for $24 \mathrm{~h}$.

Stable isotope analysis. Samples were weighed into $5 \times 8 \mathrm{~mm}$ tin capsules and analysed by the Stable Light Isotope Unit (Department of Archaeology, University of Cape Town, South Africa). The samples were com- 
busted in a Flash EA 1112 series elemental analyzer (Thermo Finnigan). The gases were passed to a Delta Plus XP IRMS (isotope ratio mass spectrometer) (Thermo Electron), via a Conflo III gas control unit (Thermo Finnigan). All stable isotope ratios are reported in the conventional delta $(\delta)$ notation as parts per thousand $(\%)$ deviation from the international standard:

$$
\delta X=\left[\left(R_{\text {sample }} / R_{\text {standard }}\right)-1\right] \times 1000
$$

where $X$ is ${ }^{13} \mathrm{C}$ or ${ }^{15} \mathrm{~N}$ and $R$ is the corresponding ratio of ${ }^{13} \mathrm{C} /{ }^{12} \mathrm{C}$ or ${ }^{15} \mathrm{~N} /{ }^{14} \mathrm{~N}$.

The global standard for the $\mathrm{C}$ isotope was Vienna PeeDee Belemnite and atmospheric nitrogen for the $\mathrm{N}$ isotope.

Statistical analysis, trophic level and source contribution to diet. Statistical analyses were conducted using SPSS version 15 for Windows. Data were checked for normality and even distribution of the residuals. One-way ANOVA was then applied to test for significant temporal or spatial differences in $\mathrm{C}$ and $\mathrm{N}$ stable isotope ratios of primary carbon sources (i.e. POM, MPB, Cladophora sp., SOM, and plant detritus) and primary consumers (Mesopodopsis africana, Pseudodiaptomus stuhlmanni, and Acartia natalensis).

The mixed model SIAR v 4.0 (stable isotope analysis in R) of Parnell et al. (2010) was used to determine the likely contribution of each of the potential food items to the diet of the mysids on both spatial and temporal scales. Primary C sources were assigned a trophic level of 1 . The $\delta^{15} \mathrm{~N}_{\text {base }}$ was chosen on the basis of its proximity to the consumer under analysis. Prior to modeling, $\delta^{15} \mathrm{~N}$ and $\delta^{13} \mathrm{C}$ values of all food categories were corrected for trophic enrichment using respective fractionation factors of 3.6 for $\delta^{15} \mathrm{~N}$ and 0.4 for $\delta^{13} \mathrm{C}$, which are appropriate for mysids according to Gorokhova \& Hansson (1999). The observation that animal tissues are enriched in $\mathrm{N}$ relative to their diets (DeNiro \& Epstein
1981) has been used in the estimation of an animal's trophic level. This can be done using the following equation modified by Post (2002):

$$
\mathrm{TL}=\lambda+\left(\delta^{15} \mathrm{~N}_{\mathrm{c}}-\delta^{15} \mathrm{~N}_{\text {base }}\right) / \Delta_{\mathrm{n}}
$$

where $\delta^{15} \mathrm{~N}_{\mathrm{c}}$ is the $\mathrm{N}$ isotopic composition of the consumer, $\delta^{15} \mathrm{~N}_{\text {base }}$ is that of the food base, $\lambda$ is the trophic level of the base ( $\lambda=1$ for primary $C$ sources), and $\Delta_{n}$ is the estimate of the average increase in $\Delta^{15} \mathrm{~N}$ per trophic level (Post 2002).

\section{RESULTS}

\section{Autotrophic sources and physico-chemical characteristics}

Temporal variations

At the Mouth, MPB biomass was greatest during the dry season, while phytoplankton biomass was greatest during the wet season. At Charters Creek, MPB and phytoplankton biomass did not change substantially between the wet and dry seasons. Salinity increased from $11 \mathrm{ppt}$ during the wet season to $16.2 \mathrm{ppt}$ during the dry season at the Mouth and increased from $46.8 \mathrm{ppt}$ during the wet season to $53.6 \mathrm{ppt}$ during the dry season at Charters Creek. Temperature was additionally always higher during the wet season (Table 1).

\section{Spatial variations}

In terms of spatial differences, phytoplankton biomass was generally greatest at the Mouth and Esengeni, decreasing further north in the system. Conversely, MPB was generally greater in the lakes than at Esengeni and the Mouth (Table 1). Organic matter

Table 1. Physico-chemical parameters and autotrophic variables measured on each of the sampling occasions during wet and dry seasons in the St. Lucia Estuary. +/-: present/absent; ns: no sample taken; PPL: phytoplankton biomass; MPB: microphyto-

\begin{tabular}{|c|c|c|c|c|c|c|c|c|c|c|}
\hline Season & Stn & 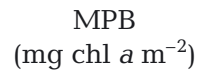 & $\begin{array}{c}\text { PPL } \\
\left(\mathrm{mg} \mathrm{chl} a \mathrm{~m}^{-3}\right)\end{array}$ & $\begin{array}{l}\text { Depth } \\
\text { (m) }\end{array}$ & $\begin{array}{c}\mathrm{DO} \\
\left(\mathrm{mg} \mathrm{l}^{-1}\right)\end{array}$ & $\begin{array}{l}\text { Salinity } \\
\text { (ppt) }\end{array}$ & $\begin{array}{c}\text { Temp. } \\
\left({ }^{\circ} \mathrm{C}\right)\end{array}$ & $\begin{array}{l}\text { Turbidity } \\
\text { (NTU) }\end{array}$ & $\begin{array}{c}\text { Detritus } \\
(+/-)\end{array}$ & $\begin{array}{l}\text { Cladophora } \\
\text { sp. (+/-) }\end{array}$ \\
\hline \multicolumn{11}{|c|}{ Spatial study } \\
\hline \multirow{4}{*}{ Wet } & Mouth & 5.15 & 61.5 & 2 & 5.23 & 8.52 & 21.9 & 62.6 & + & - \\
\hline & Esengeni & 24.5 & 51.2 & 1.2 & 6.74 & 2.55 & 21 & 17.5 & - & - \\
\hline & Catalina Bay & 151 & 11 & 0.2 & 5.69 & 18.6 & 28.6 & 43 & - & - \\
\hline & Charters Creek & 34.2 & 4.94 & 0.2 & 7.69 & 46.8 & 26.8 & 102 & - & + \\
\hline \multicolumn{11}{|c|}{ Temporal study } \\
\hline Wet & Mouth & 5.15 & 68.5 & 5 & 7.16 & 11 & 27.6 & 21.9 & + & - \\
\hline Dry & Mouth & 72.5 & 23.9 & 4 & 7.63 & 16.2 & 19.6 & 10.1 & + & - \\
\hline Wet & Charters Creek & 34.2 & 4.94 & 0.2 & 7.69 & 46.8 & 26.8 & 102 & + & + \\
\hline Dry & Charters Creek & 17.9 & 4.98 & 0.1 & 8.45 & 53.6 & 21.5 & 341 & ns & + \\
\hline
\end{tabular}
benthic biomass; DO: dissolved oxygen; NTU: nephelometric turbidity units 
fraction in the sediment increased towards the north. $\%$ SOM ranged from $0.84 \%$ at the Mouth to $3.58 \%$ at Charters Creek. Cladophora sp. was only present at Charters Creek and was found in both the wet and the dry season (Table 1). The St. Lucia estuarine lake was characterized by a reversed salinity gradient. Salinity ranged from 2.55 ppt at Esengeni to $>46.8$ ppt at Charters Creek. Water temperatures ranged from 19.6 to $27.6^{\circ} \mathrm{C}$. Turbidity varied between stations, being lowest at Esengeni and highest at Charters Creek. Water depths were greatest at the Mouth and Esengeni, while those at Catalina Bay and Charters Creek were much shallower (Table 1).

\section{Stable isotopes}

\section{Temporal variations}

Despite increased rainfall and temperatures in the wet season, there was no significant temporal difference in the $\delta^{13} \mathrm{C}$ values of the primary $\mathrm{C}$ sources at the
Mouth (ANOVA, $\left.F_{1,20}=1.61, \mathrm{p}>0.05\right)$. The $\delta^{13} \mathrm{C}$ signatures of all the primary $\mathrm{C}$ sources at the Mouth were significantly different to each other (ANOVA, $F_{3,18}=$ 78.7, $\mathrm{p}<0.05$ ) and ranged from -13.81 to $-29.25 \%$. In both wet and dry seasons, MPB was most enriched in $\delta^{13} \mathrm{C}$, while POM was most depleted (Fig. 2a,b). $\delta^{13} \mathrm{C}$ signatures of the primary $\mathrm{C}$ sources at Charters Creek differed significantly between seasons (ANOVA, $F_{1,20}=$ 13.7, $\mathrm{p}<0.01)$. All sources of organic $C$ were significantly different at Charters Creek (ANOVA, $F_{2,19}=$ $10.2, \mathrm{p}<0.01$ ) with the exception of POM and MPB (post hoc Tukey's HSD, $\mathrm{p}>0.05$ ). Overall, $\delta^{13} \mathrm{C}$ signatures of primary $\mathrm{C}$ sources at Charters Creek ranged from -15.7 to $-24.2 \%$, with Cladophora sp. having the most enriched $\delta^{13} \mathrm{C}$ signature, while POM and SOM $\delta^{13} \mathrm{C}$ signatures were the most depleted (Fig. 2c,d). At both the Mouth and Charters Creek, $\delta^{13} \mathrm{C}$ signatures of the primary $\mathrm{C}$ sources, particularly POM, were generally more enriched (+ 1 to $2 \%$ ) during the wet season (Table 2).

For the primary consumers, Pseudodiaptomus stuhlmanni and Mesopodopsis africana, $\delta^{13} \mathrm{C}$ signatures at
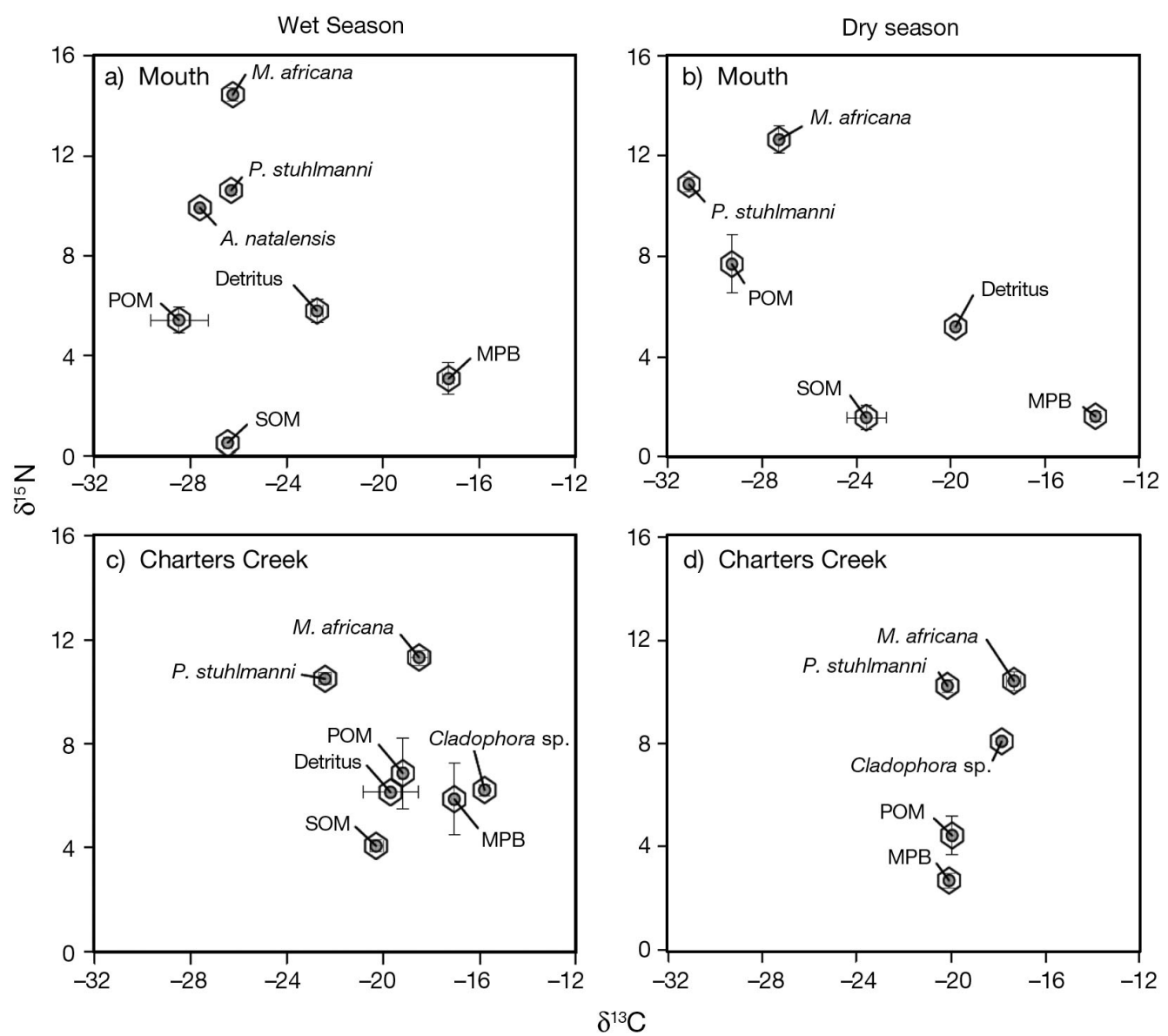

Fig. 2. $\delta^{13} \mathrm{C}$ and $\delta^{15} \mathrm{~N}$ of primary $\mathrm{C}$ sources and primary consumers sampled at the Mouth (a,b) and at Charters Creek (c,d) during wet $(\mathrm{a}, \mathrm{c})$ and dry $(\mathrm{b}, \mathrm{d})$ seasons. M. africana: Mesopodopsis africana; P. stuhlmanni: Pseudodiaptomas stuhlmanni; POM: particulate organic matter; SOM: sedimentary organic matter; MPB: microphytobenthic biomass. Error bars: SD 
Table 2. Average $\delta^{13} \mathrm{C}$ and $\delta^{15} \mathrm{~N}$ values $( \pm \mathrm{SD}$ ) of the primary $\mathrm{C}$ sources and primary consumers during wet and dry seasons in the St. Lucia Estuary. -: absent; ns: no sample taken; POM: particulate organic matter; MPB: microphytobenthic biomass; SOM: sedimentary organic matter; wet/dry: wet/dry season

\begin{tabular}{|c|c|c|c|c|c|c|c|c|c|}
\hline & & & POM & MPB & SOM & Detritus & $\begin{array}{c}\text { Cladophora } \\
\text { sp. }\end{array}$ & $\begin{array}{l}\text { Pseudodiaptomus } \\
\text { stuhlmanni }\end{array}$ & $\begin{array}{c}\text { Mesopodopsis } \\
\text { africana }\end{array}$ \\
\hline \multicolumn{10}{|c|}{ Spatial study } \\
\hline \multirow[t]{4}{*}{ Wet } & Mouth & $\begin{array}{l}\delta^{13} \mathrm{C} \\
\delta^{15} \mathrm{~N}\end{array}$ & $\begin{array}{r}-25.3 \pm 0.2 \\
8.5 \pm 0.2\end{array}$ & $\begin{array}{r}-15.5 \pm 0.01 \\
5.56 \pm 0.45\end{array}$ & $\begin{array}{r}-25.0 \pm 0.1 \\
5.01 \pm 0.08\end{array}$ & $\begin{array}{l}\text { ns } \\
\text { ns }\end{array}$ & - & $\begin{array}{r}-30.3 \pm 0.2 \\
11.8 \pm 1.0\end{array}$ & $\begin{array}{c}-27.3 \pm 0.41 \\
14.1 \pm 0.2\end{array}$ \\
\hline & Esengeni & $\begin{array}{l}\delta^{13} \mathrm{C} \\
\delta^{15} \mathrm{~N}\end{array}$ & $\begin{aligned}-24.1 & \pm 0.41 \\
4.9 & \pm 0.1\end{aligned}$ & $\begin{array}{r}-20.1 \pm 0.18 \\
4.07 \pm 0.08\end{array}$ & $\begin{array}{r}-21.6 \pm 0.06 \\
5.7 \pm 0.08\end{array}$ & $\begin{array}{l}\text { ns } \\
\text { ns }\end{array}$ & - & $\begin{array}{r}-27.9 \pm 0.17 \\
7.0 \pm 0.25\end{array}$ & $\begin{array}{r}-25.9 \pm 0.27 \\
10.0 \pm 0.31\end{array}$ \\
\hline & Catalina Bay & $\begin{array}{l}\delta^{13} \mathrm{C} \\
\delta^{15} \mathrm{~N}\end{array}$ & $\begin{aligned}-19.4 & \pm 0.21 \\
8.84 & \pm 0.83\end{aligned}$ & $\begin{array}{l}\mathrm{ns} \\
\mathrm{ns}\end{array}$ & $\begin{aligned}-17.0 & \pm 0.02 \\
4.16 & \pm 0.02\end{aligned}$ & $\begin{array}{l}\mathrm{ns} \\
\mathrm{ns}\end{array}$ & $\begin{array}{l}- \\
-\end{array}$ & $\begin{array}{l}- \\
-\end{array}$ & $\begin{array}{r}-18.4 \pm 0.17 \\
11.3 \pm 0.27\end{array}$ \\
\hline & Charters Creek & $\begin{array}{l}\delta^{13} \mathrm{C} \\
\delta^{15} \mathrm{~N}\end{array}$ & $\begin{array}{r}-19.1 \pm 0.13 \\
6.86 \pm 1.36\end{array}$ & $\begin{array}{r}-17.0 \pm 0.11 \\
5.86 \pm 1.38\end{array}$ & $\begin{array}{r}-20.2 \pm 0.83 \\
4.05 \pm 1.21\end{array}$ & $\begin{array}{r}-19.7 \pm 0.64 \\
6.12 \pm 0.02\end{array}$ & $\begin{array}{r}-15.7 \pm 0.07 \\
6.2 \pm 0.22\end{array}$ & $\begin{array}{r}-22.3 \pm 0.26 \\
10.5 \pm 0.22\end{array}$ & $\begin{array}{r}-18.4 \pm 0.37 \\
11.3 \pm 0.29\end{array}$ \\
\hline \multicolumn{10}{|c|}{ Temporal study } \\
\hline Wet & Mouth & $\begin{array}{l}\delta^{13} \mathrm{C} \\
\delta^{15} \mathrm{~N}\end{array}$ & $\begin{array}{r}-27.6 \pm 1.18 \\
5.84 \pm 1.28\end{array}$ & $\begin{array}{r}-17.3 \pm 0.23 \\
3.08 \pm 0.63\end{array}$ & $\begin{array}{r}-26.33 \\
0.5\end{array}$ & $\begin{aligned}-22.7 & \pm 0.25 \\
5.8 & \pm 0.46\end{aligned}$ & $\begin{array}{l}- \\
-\end{array}$ & $\begin{array}{r}-26.3 \pm 0.09 \\
10.6 \pm 0.18\end{array}$ & $\begin{array}{r}-26.2 \pm 0.01 \\
14.4 \pm 0.25\end{array}$ \\
\hline Dry & Mouth & $\begin{array}{l}\delta^{13} \mathrm{C} \\
\delta^{15} \mathrm{~N}\end{array}$ & $\begin{aligned}-29.3 & \pm 0.04 \\
7.70 & \pm 1.16\end{aligned}$ & $\begin{aligned}-13.8 & \pm 0.03 \\
1.67 & \pm 0.22\end{aligned}$ & $\begin{aligned}-23.6 & \pm 0.83 \\
1.63 & \pm 0.47\end{aligned}$ & $\begin{array}{r}-19.8 \pm 0.05 \\
5.20 \pm 0.04\end{array}$ & $\begin{array}{l}- \\
-\end{array}$ & $\begin{array}{r}-31.1 \pm 0.02 \\
10.8 \pm 0.31\end{array}$ & $\begin{array}{r}-27.3 \pm 0.13 \\
12.6 \pm 0.53\end{array}$ \\
\hline Wet & Charters Creek & $\begin{array}{l}\delta^{13} \mathrm{C} \\
\delta^{15} \mathrm{~N}\end{array}$ & $\begin{aligned}-19.1 & \pm 0.13 \\
6.86 & \pm 1.36\end{aligned}$ & $\begin{aligned}-17.0 & \pm 0.11 \\
5.86 & \pm 1.38\end{aligned}$ & $\begin{aligned}-20.2 & \pm 0.83 \\
4.05 & \pm 1.21\end{aligned}$ & $\begin{aligned}-19.6 & \pm 1.07 \\
6.13 & \pm 0.02\end{aligned}$ & $\begin{aligned}-15.7 & \pm 0.08 \\
6.20 & \pm 0.22\end{aligned}$ & $\begin{array}{r}-22.3 \pm 0.26 \\
10.5 \pm 0.22\end{array}$ & $\begin{array}{r}-18.4 \pm 0.37 \\
11.3 \pm 0.29\end{array}$ \\
\hline Dry & Charters Creek & $\begin{array}{l}\delta^{13} \mathrm{C} \\
\delta^{15} \mathrm{~N}\end{array}$ & $\begin{array}{r}-20.0 \pm 0.12 \\
4.43 \pm 0.76\end{array}$ & $\begin{array}{r}-20.1 \pm 0.04 \\
2.68 \pm 0.28\end{array}$ & $\begin{array}{ll}\text { ns } \\
\text { ns }\end{array}$ & $\begin{array}{l}\mathrm{ns} \\
\mathrm{ns}\end{array}$ & $\begin{array}{r}-17.9 \pm 0.06 \\
8.08 \pm 0.12\end{array}$ & $\begin{array}{r}-20.2 \pm 0.03 \\
10.2 \pm 0.25\end{array}$ & $\begin{aligned}-17.4 & \pm 0.3 \\
10.4 & \pm 0.37\end{aligned}$ \\
\hline
\end{tabular}

the Mouth during the wet season were significantly more enriched than those during the dry season (ANOVA, $M$. africana: $F_{1,3}=211, \mathrm{p}<0.001 ; P$. stuhlmanni: $\left.F_{1,3}=5065, \mathrm{p}<0.001\right)$. Conversely, $\delta^{13} \mathrm{C}$ signatures of these 2 species at Charters Creek were significantly more enriched during the dry season compared to the wet season (ANOVA, M. africana: $F_{1,7}=21.5, \mathrm{p}<0.001 ;$ P. stuhlmanni: $F_{1,5}=289, \mathrm{p}<$ 0.001) (Fig. 2, Table 2).

While there was no significant temporal variation in $\delta^{15} \mathrm{~N}$ signatures of the primary $\mathrm{C}$ sources (ANOVA, Mouth: $F_{1,20} 0.41, \mathrm{p}>0.05$; Charters Creek: $F_{1,20}=0.35$, $\mathrm{p}>0.05)$, the sources were significantly different to each other (ANOVA, Mouth: $F_{3,18}=32$, p < 0.001; Charters Creek: $\left.F_{2,19}=7.45, \mathrm{p}<0.001\right) . \delta^{15} \mathrm{~N}$ signatures of the primary $\mathrm{C}$ sources ranged from $0.5 \%$ for SOM to $7.7 \%$ POM at the Mouth (Fig. 2, Table 2). At the Mouth and Charters Creek, $\delta^{15} \mathrm{~N}$ signatures for Mesopodopsis africana were higher during the wet season. For Pseudodiaptomus stuhlmanni, however, values were relatively stable between seasons (Fig. 2, Table 2).

\section{Spatial variations}

$\delta^{13} \mathrm{C}$ values of the primary $\mathrm{C}$ sources at the Mouth and Esengeni were significantly more depleted than those at Charters Creek (ANOVA, $F_{3,33}=6.27, \mathrm{p}<$ 0.01). While the $\delta^{13} \mathrm{C}$ values of the primary $\mathrm{C}$ sources at the Mouth, Esengeni, and Catalina Bay were all significantly different from each other (ANOVA, p < 0.01), SOM and detritus $\delta^{13} \mathrm{C}$ values were not significantly different to those of POM at Charters Creek (post hoc Tukey's HSD, p > 0.05). As for the primary consumers, $\delta^{13} \mathrm{C}$ signatures became less depleted with distance from the estuary mouth (ANOVA, Mesopodopsis africana: $F_{3,15}=1065, \mathrm{p}<0.001$; Pseudodiaptomus stuhlmanni: $\left.F_{2,5}=932, \mathrm{p}<0.001\right)$. $\delta^{13} \mathrm{C}$ signatures ranged from -30.3 to $-22.3 \%$ or $P$. stuhlmanni and from -27.3 to $-18.4 \%$ for M. africana (Fig. 3, Table 2).

The $\delta^{15} \mathrm{~N}$ signatures of the primary producers were fairly similar between sites (ANOVA, $F_{3,33}=2.52, \mathrm{p}>$ 0.05 ), ranging from $\sim 4$ to $\sim 9 \%$. Among the primary consumers, Mesopodopsis africana was most enriched in nitrogen at the Mouth, with a $\delta^{15} \mathrm{~N}$ of $14.1 \%$. $\delta^{15} \mathrm{~N}$ signals at Esengeni, Catalina Bay, and Charters Creek were 10,11.4, and $11.3 \%$, respectively. For Pseudodiaptomus stuhlmanni, $\delta^{15} \mathrm{~N}$ signatures at the Mouth $(11.8 \%$ ) were slightly higher than those at Esengeni and Charters Creek, with values of 11.8, 7.0 and $10.5 \%$, respectively (Fig. 3, Table 2).

Trophic level and source contribution to diet

The trophic levels of the primary consumers varied slightly between wet and dry seasons. There were no significant temporal differences in trophic level at the Mouth (ANOVA, Mesopodopsis africana: $F_{1,3}=4.00$, 

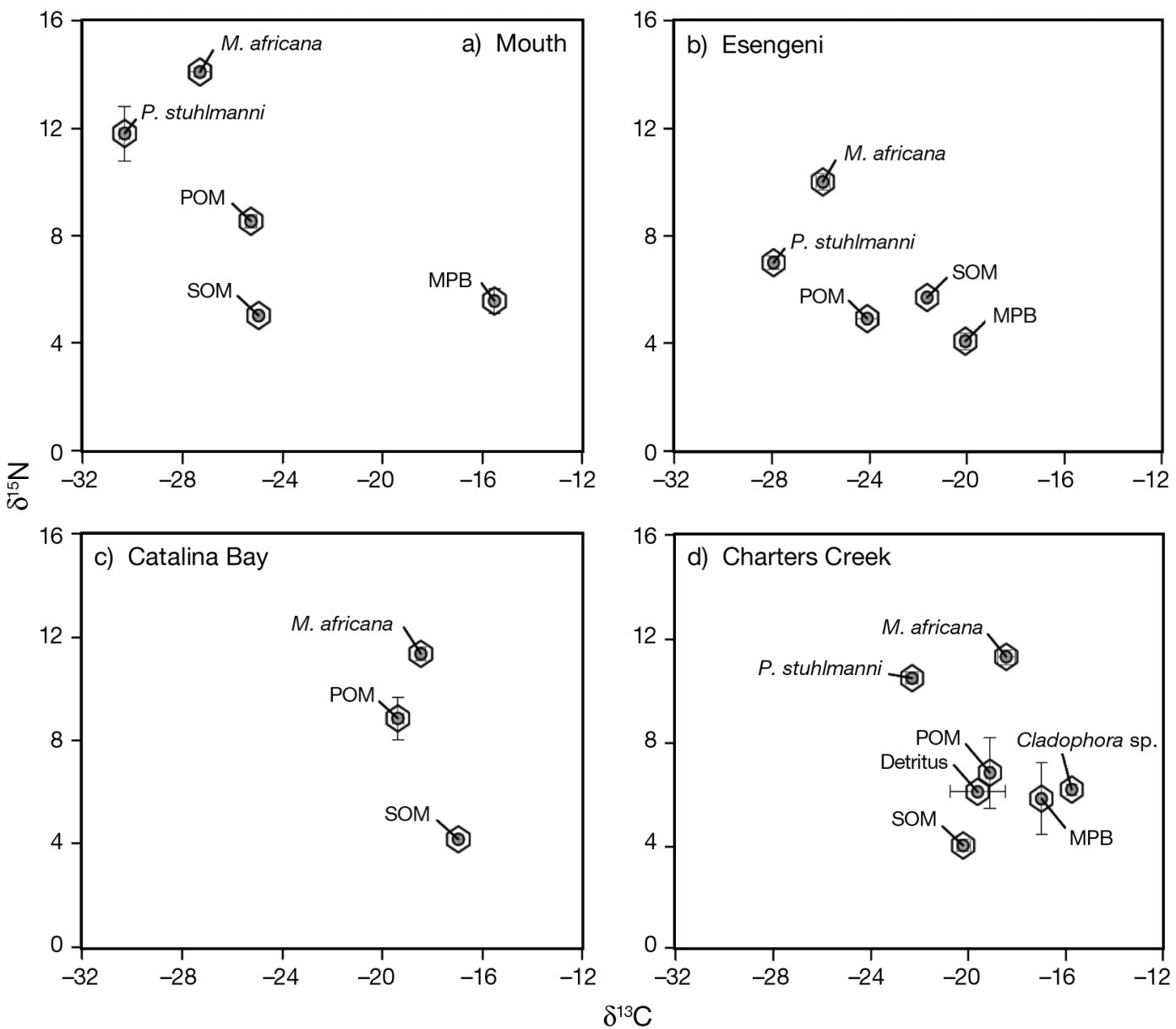

Fig. 3. $\delta^{13} \mathrm{C}$ and $\delta^{15} \mathrm{~N}$ of primary $\mathrm{C}$ sources and primary consumers sampled at (a) the Mouth, (b) Esengeni, (c) Catalina Bay, and (d) Charters Creek. Abbreviations see Fig. 2. Error bars: SD

$\mathrm{p}>0.05$; Pseudodiaptomus stuhlmanni: $F_{1,3}=0.38, \mathrm{p}>$ 0.05). M. africana was most enriched in $\delta^{15} \mathrm{~N}$ during the wet season and, therefore, occupied the highest trophic position (3.39) followed by P. stuhlmanni (2.35) and Acartia natalensis (2.2) at the Mouth. During the dry season at the Mouth, $M$. africana occupied the highest trophic level (2.71), followed by P. stuhlmanni (2.21). The trophic levels of primary consumers at Charters Creek did vary significantly from wet to dry seasons (ANOVA, $M$. africana: $F_{1,7}=87.5, \mathrm{p}<0.001 ; P$. stuhlmanni: $\left.F_{1,5}=143, \mathrm{p}<0.001\right)$. Among the primary consumers at Charters Creek, $M$. africana had the highest trophic level (2.23), followed closely by $P$. stuhlmanni (2.07) in the wet season, but in the dry season it was Rhopalophthalmus tropicalis that was identified as the highest trophic level (2.89), followed by $P$. stuhlmanni (2.61) and lastly $M$. africana (1.65). The trophic levels of primary consumers varied significantly between stations (ANOVA, $M$. africana: $F_{3,15}=126, \mathrm{p}<$ 0.001; $P$. stuhlmanni: $\left.F_{2,5}=7.74, \mathrm{p}<0.05\right)$. These differences were more pronounced for $M$. africana, which exhibited a significantly higher trophic level at the Mouth and Esengeni than at Catalina Bay and Charters Creek (post hoc Tukey's HSD, p <0.01).

The SIAR v 4.0 mixed model resolved proportions of different food sources in the diet of Mesopodopsis africana. Contribution of different $\mathrm{C}$ sources to the diet of $M$. africana was relatively constant between wet and dry seasons at the Mouth (Fig. 4). In the wet season (Fig. 4a), the copepods Pseudodiaptomus stuhlmanni and Acartia natalensis were the most important components of the mysid diet, contributing up to 52 and $46 \%$, respectively. Next important was SOM (up to $34 \%$ ), followed by POM and plant detritus, contributing up to $\sim 29 \%$ of the mysid diet. In the dry season (Fig. 4b), P. stuhlmanni contributed between 13 to $74 \%$ of the diet, followed by POM. At Charters Creek, the relative proportions of the $\mathrm{C}$ sources in the diet of $M$. africana changed slightly from wet to dry seasons, with Cladophora sp. being in both cases the most important dietary item, followed by $P$. stuhlmanni and POM (Fig. 4c,d). 


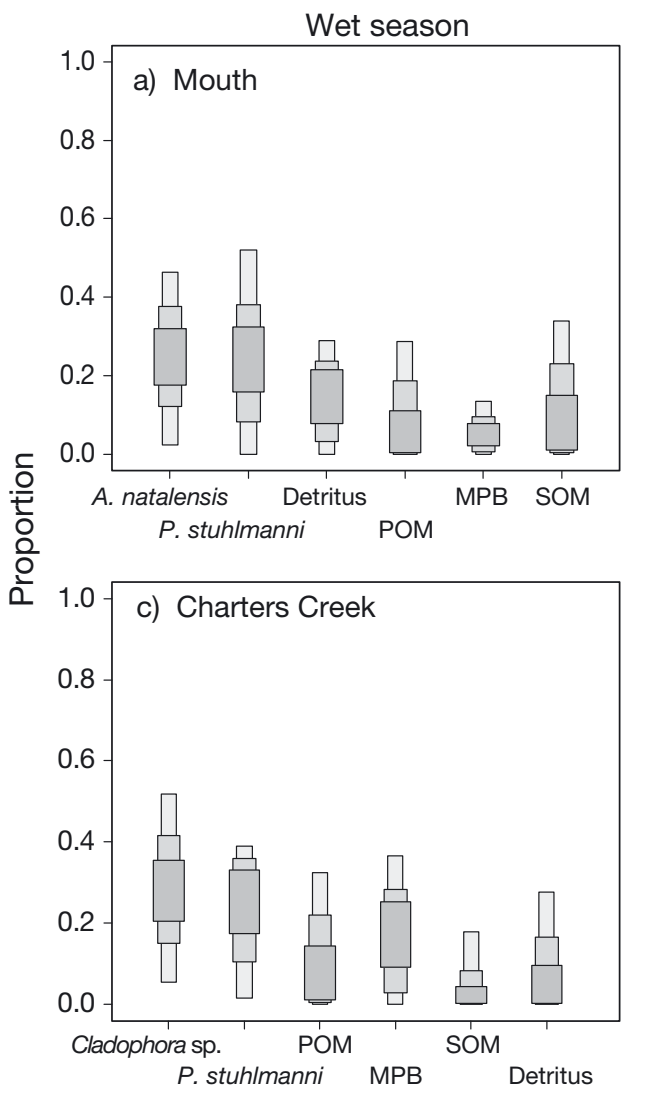

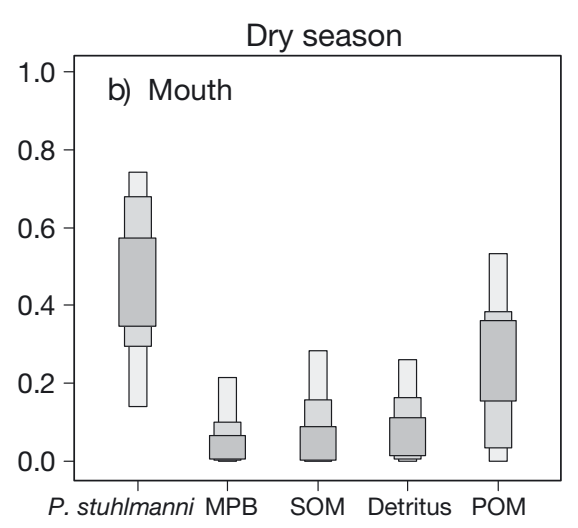

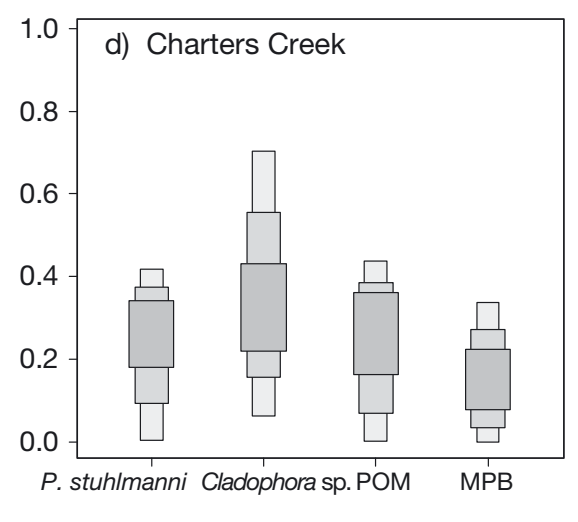

Fig. 4. Boxplot showing the contribution of different primary $\mathrm{C}$ sources to the diet of Mesopodopsis africana using stable isotope analysis in $\mathrm{R}$ (SIAR) at the Mouth $(a, b)$ and at Charters Creek (c,d) during wet $(\mathrm{a}, \mathrm{c})$ and dry seasons $(b, d)$. Abbreviations see Fig. 2. The proportions show the credibility intervals plotted at 95,75 , and $25 \%$
The contribution of different $\mathrm{C}$ sources to the diet of Mesopodopsis africana also varied spatially (Fig. 5). At the Mouth and Esengeni, Pseudodiaptomus stuhlmanni contributed the greatest proportion to the mysid diet, with 41 to $76 \%$ of the diet at the Mouth and 48 to $69 \%$ at Esengeni. Next important in terms of diet contribution was POM, contributing up to $47 \%$ of the diet at the Mouth and $32 \%$ at Esengeni. SOM and MPB made minor contributions to their overall diet. The copepod P. stuhlmanni was absent during this survey at Catalina Bay. At this station, POM made the greatest contribution to the mysid diet, followed by SOM and MPB. At Charters Creek, Cladophora sp. made the most substantial contribution to the mysid diet, accounting for up to $52 \%$ of the diet, while MPB and $P$. stuhlmanni contributed between 0 and $40 \%$ of the diet (Fig. 5).

\section{DISCUSSION}

The present study demonstrates the ability of Mesopodopsis africana to modify its diet in response to different environmental conditions on short temporal and spatial scales within the same system. The nature of freshwater deprivation in the St. Lucia Estuary has resulted in a northward gradient of drought effects.
While regions in the south have recently been relatively protected from the drought due to freshwater input from the Mpate and Mfolozi Rivers through the link canal (Whitfield \& Taylor 2009), hypersalinity and low water levels have become increasingly more severe towards the north. This profile has fractionated the system into a variety of different habitats in relatively close range to one another. The potential omnivorous feeding habits of mysids (cf. Mauchline 1980, Lehtiniemi \& Nordström 2008, Vilas et al. 2008) have thus allowed this species to rapidly modify its diet in accordance with changes in food type and abundance.

Spatial differences in isotope signatures seemed to be greater than temporal variations. This was not surprising given the vast differences between sites due to habitat fragmentation. In terms of seasonality, on the eastern seaboard of South Africa, the rainy season extends from October to April and the dry season from May to September. However, recent estimates indicate that only $\sim 24 \%$ of the normal freshwater inflow is currently entering the St. Lucia Estuary from the catchments (D. Stretch pers. comm.). During the study, $\delta^{13} \mathrm{C}$ values were slightly raised during the wet season. Allanson \& Read (1987, 1995) demonstrated that increased freshwater input to a system promotes phytoplankton primary production through macronutrient availability and water-column stability. The 


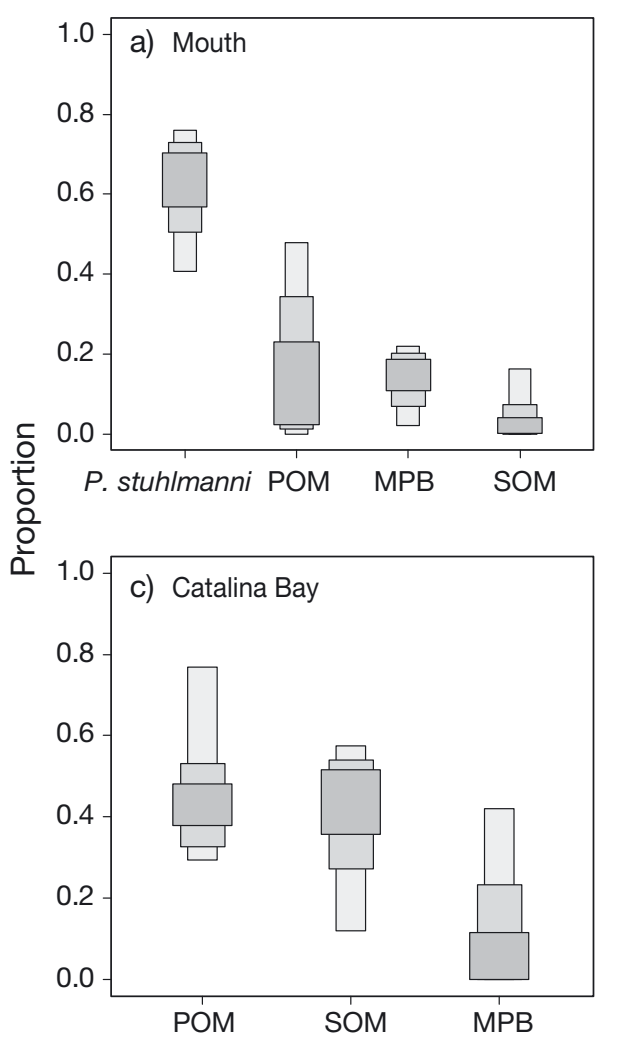

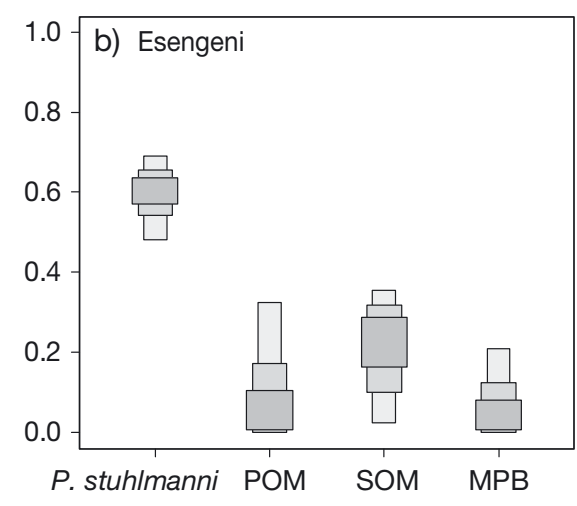

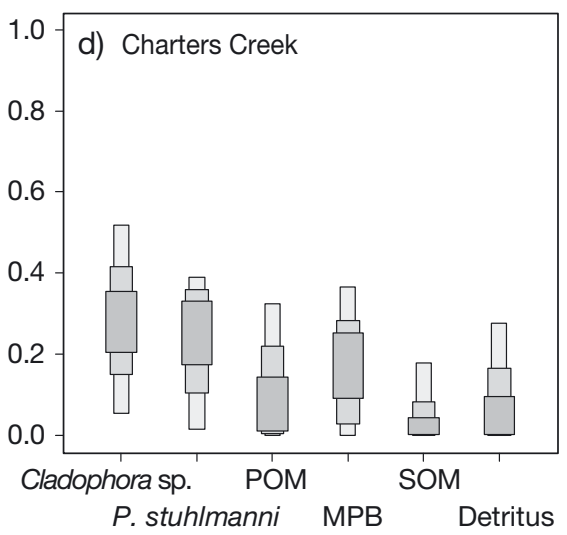

Fig. 5. Boxplot showing the contribution of different primary C sources to the diet of Mesopodopsis africana using SIAR at 4 stations within the St. Lucia Estuary, (a) the Mouth, (b) Esengeni, (c) Catalina Bay, and (d) Charters Creek. Abbreviations see Fig. 2. The proportions show the credibility intervals plotted at 95,75 , and $25 \%$ slightly raised $\delta^{13} \mathrm{C}$ values observed in the wet season in the St. Lucia Estuary may, therefore, be a reflection of the increase in phytoplankton biomass and primary production by the addition of nutrients. Goering et al. (1990) found that plankton $\delta^{13} \mathrm{C}$ values increased by $\sim 2 \%$ during a phytoplankton bloom. It has been suggested that changes in phytoplankton assemblages can affect the $\delta^{13} \mathrm{C}$ composition of the marine ecosystem by $>10 \%$ (Fogel et al. 1992).

$\delta^{13} \mathrm{C}$ signatures of POM at the Mouth and Esengeni were more depleted than those at Charters Creek and Catalina Bay. Signatures in the mouth region were closer to $\delta^{13} \mathrm{C}$ signatures of mangrove leaves ( -31.2 to $-26.8 \%$; Bouillon et al. 2004). An explanation for this could be that the POM contained material that originated from senescent leaves of mangroves (N. Govender pers. comm.), a habitat located near and around the Mouth and Narrows region (Begg 1978). Additionally, the Mouth and Esengeni have recently received a steady riverine input (Whitfield \& Taylor 2009). Depleted C signatures could, therefore, also reflect allochthonous input upstream. $\delta^{13} \mathrm{C}$ signatures of terrestrial fringing vegetation such as Salicornia sp. at Catalina Bay and Phragmites sp. at Esengeni ranged from -29.01 to $-29.4 \%$ and from -28 to $-19 \%$, respectively. These values are similar to those recorded for POM in the Mouth region, suggesting that allochtho- nous input most probably contained $\delta^{13} \mathrm{C}$-depleted terrestrial detritus. The trend of an increase in $\delta^{13} \mathrm{C}$ values of POM along an estuarine gradient was recorded by Fontugne \& Jouanneau (1987) and confirmed by similar studies on other hydrosystems (Riera \& Richard 1996, Bardonnet \& Riera 2005, Suzuki et al. 2008). It can be attributed to the gradual mixing together of sources of fluvial (light $\delta^{13} \mathrm{C}$ ) and marine (heavy $\delta^{13} \mathrm{C}$ ) organic matter (Fontugne \& Jouanneau 1987).

Mysids are generally regarded as omnivores, capable of successfully exploiting a variety of food resources. Diet may include phytobenthos, phytoplankton, detritus, sediment, microzooplankton, mesozooplankton, and small benthic invertebrates (Wilhelm et al. 2002, Kibirige \& Perissinotto 2003, Lehtiniemi \& Nordström 2008, Vilas et al. 2008). $\delta^{15} \mathrm{~N}$ signals for Mesopodopsis africana in the present study ranged from 10 to $14 \%$. These values are similar to those recorded by Rolff et al. (1993) and Rolff (1998) for Mysis mixta in the northern Baltic Sea, and within the range of those recorded for $M$. stenolepsis and Neomysis americana in the St. Lawrence Estuary of Canada, and suggest that mysids may be feeding predominantly on mesozooplankton (Winkler et al. 2007). Diet analysis using SIAR v 4.0 showed that mysids at the Mouth and Esengeni occupied higher trophic levels, feeding mainly on the calanoid copepod Pseudodiapto- 
mus stuhlmanni. POM was, however, the main food source for M. africana at Catalina Bay. This could be because the copepods were absent from this station at the time. These results indicate that mysid diet changes with food availability. Jerling \& Wooldridge (1995) found that the mysids Mesopodopsis wooldrigei and Rhopalophthalmus terranatalis in the Sundays River Estuary (South Africa) preferentially fed on nauplii as opposed to copepodites, due to the high abundance of nauplii in the water column. Diet shifts according to food availability have also been previously recorded in other studies (Viherluoto et al. 2000, Winkler et al. 2007, Vilas et al. 2008). Feeding on POM may, therefore, be a result of mysids feeding on the most abundant prey, rather than selective feeding. The flexibility in the diet of $M$. africana is also shown on a temporal scale. While the dominant food items for $M$. africana did not change significantly from wet to dry seasons, the proportions of the different sources in the mysid diet varied. This again may be linked to food availability.

The diet of Mesopodopsis africana at Charters Creek was also slightly more difficult to quantify, since it appeared as though all sources were making similar contributions to the diet. This could be because of the greater number of autotrophic sources available, or it could be a reflection of not all the $\delta^{13} \mathrm{C}$ sources being significantly different. Herwig et al. (2007) stated that lack of separation of several primary food sources made identification of the sources of organic matter that supported secondary production in the main channel of the Mississippi River difficult. The general lack of 1 dominant food source at Charters Creek may also reflect the harsh environmental conditions present in this area at the time. Charters Creek is situated on the western shores of South Lake, which is known to be a turbid location (Cyrus 1988). Here, shallow waters combined with a fine sandy substratum frequently lead to turbidities exceeding 300 nephelometric turbidity units (NTU). Carrasco et al. (2007) documented the negative effect of high turbidity on the feeding and mortality rates of $M$. africana. Additionally, zooplankton communities at Charters Creek may have been more stressed on account of freshwater starvation and the resultant hypersalinity and low water levels. It could be assumed that under stressful conditions, zooplankton may become less selective in their prey choice. Diet shifts in mysids have previously been reported and related to food availability (Viherluoto et al. 2000, Winkler et al. 2007, Vilas et al. 2008). That is, in order to complete their diet, mysids show a more opportunistic behaviour when resources are limited. Additionally, Tackx et al. (2003) demonstrated the limited ability of Eurytemora affinis to feed selectively under high suspended particulate matter loads.
While Mesopodopsis africana is a euryhaline species, capable of surviving salinities from 2.5 to $65 \mathrm{ppt}$ (N. Carrasco pers. obs.), continued drought effects could force the exclusion of this species. M. africana is an important connecting species in the St. Lucia Estuary, linking primary and secondary production with higher trophic levels (Mees \& Jones 1997, Viherluoto \& Viitasalo 2001, Lehtiniemi et al. 2009). Blaber (1979) documented their importance in the diet of zooplanktivorous fish such as Gilchristella aestuaria, Hilsa kelee, and Thryssa vitrirostris in the St. Lucia Estuary. In particular, $M$. africana was second in importance in terms of calorific contribution after Pseudodiaptomus stuhlmanni (Blaber 1979). Its loss would, therefore, have substantial impacts on food web functioning in different regions of this key estuarine lake. The potential though for this mysid to alter its diet in response to a dynamic environment, such as St. Lucia, and its persistence through the many past hydrological phases, is a prime example of its adaptive nature and re-enforces the resilience so far shown by the system.

Acknowledgements. Sincere thanks go to the iSimangaliso Wetland Park Authority and the staff and management of Ezemvelo Kwa-Zulu-Natal (EKZN) Wildlife. Special mention must be made of Ricky Taylor and Caroline Fox for their support throughout this study. Holly Nel, Garrett Kruger, and Nelson Miranda are gratefully acknowledged for their help in the field. Funding for this project was provided by the National Research Foundation (NRF, Pretoria), Marine and Coastal Management (MCM, Cape Town) and the World Wide Fund (WWF).

\section{LITERATURE CITED}

Allanson BR, Read GHL (1987) The response of estuaries along the south eastern coast of southern Africa to marked variation in freshwater inflow. Institute of Freshwater Studies: Final report. Rhodes University, Grahamstown

Allanson BR, Read GHL (1995) Further comment on the response of eastern Cape Province estuaries to variable freshwater inflows. South Afr J Aquat Sci 21:56-70

Bardonnet A, Riera P (2005) Feeding of glass eels (Anguilla anguilla) in the course of their estuarine migration: new insights from stable isotope analysis. Estuar Coast Shelf Sci 63:201-209

Begg G (1978) The estuaries of Natal. Report no. 41, Natal Town and Regional Planning Commision, Pietermaritzburg

Blaber SJM (1979) The biology of filter feeding teleosts in Lake St. Lucia, Zululand. J Fish Biol 15:37-59

Bligh EG, Dyer RM (1959) A rapid method of total lipid extraction and purification. Can J Biochem Physiol 37:911-917

Bouillon S, Moen T, Dehairs F (2004) Carbon sources supporting benthic mineralization in mangrove and adjacent seagrass sediments (Gazi Bay, Kenya). Biogeosciences 1: $71-78$

> Carrasco NK, Perissinotto R, Miranda NAF (2007) Effects of silt loading on the feeding and mortality of the mysid Mesopodopsis africana in the St. Lucia Estuary, South Africa. J Exp Mar Biol Ecol 352:152-164 
Carrasco NK, Perissinotto R, Pillay D (2010) Zooplankton of the St. Lucia Estuary during the current drought cycle: a comparison between open- and closed-mouth conditions. Mar Ecol Prog Ser 399:157-171

Couch CA (1989) Carbon and nitrogen stable isotopes of meiobenthos and their food resources. Estuar Coast Shelf Sci 28:433-441

Cyrus DP (1988) Turbidity and other physical factors in Natal estuarine systems. II. Estuarine lakes. J Limnol Soc South Afr 14:72-81

Cyrus DP, Vivier L (2006) Status of the estuarine fish fauna in the St. Lucia Estuarine System, South Africa, after 30 months of mouth closure. Afri J Aquat Sci 31:71-81

DeNiro MJ, Epstein S (1978) Influence of diet on the distribution of carbon isotopes in animals. Geochim Cosmochim Acta 42:495-506

DeNiro MJ, Epstein S (1981) Influence of diet on the distribution of nitrogen isotopes in animals. Geochim Cosmochim Acta 45:341-351

Fielding PJ, Forbes AT, Demetriades NT (1991) Chlorophyll concentrations and suspended particulate loads in St. Lucia, a turbid estuary on the east coast of South Africa. S Afr J Mar Sci 11:491-498

Fogel ML, Cifuentes LA, Velinsky DJ, Sharp JH (1992) Relationship of carbon availability in estuarine phytoplankton to isotopic composition. Mar Ecol Prog Ser 82:291-300

Fontugne MR, Jouanneau JM (1987) Modulation of the particulate organic-carbon flux to the ocean by a macrotidal estuary-evidence from measurements of carbon isotopes in organic-matter from the Gironde system. Estuar Coast Shelf Sci 24:377-387

Fulton RS (1982) Predatory feeding of 2 marine mysids. Mar Biol 72:183-191

Goering J, Alexander V, Haubenstock N (1990) Seasonal variability of stable carbon and nitrogen isotope ratios of organisms in a North Pacific bay. Estuar Coast Shelf Sci 30:239-260

Gorokhova E, Hansson S (1999) An experimental study on variations in stable carbon and nitrogen isotope fractionation during growth of Mysis mixta and Neomysis integer. Can J Fish Aquat Sci 56:2203-2210

Hansson S, Larsson U, Johansson S (1990) Selective predation by herring and mysids, and zooplankton community structure in a Baltic Sea coastal area. J Plankton Res 12: 1099-1116

Herwig BR, Wahl DH, Detters JM, Soluk DA (2007) Spatial and temporal patterns in the food web structure of a large floodplain river assessed using stable isotopes. Can J Fish Aquat Sci 64:495-508

Hughes RN (1980) Optimal foraging theory in the marine context. Oceanogr Mar Biol Annu Rev 18:423-481

Jerling H, Wooldridge T (1995) Feeding of two mysid species on plankton in a temperate South African estuary. J Exp Mar Biol Ecol 188:243-259

Kibirige I, Perissinotto R (2003) The zooplankton community of the Mpenjati Estuary, a South African temporarily open/closed system. Estuar Coast Shelf Sci 58:727-741

Kibirige I, Perissinotto R, Thwala X (2006) A comparative study of zooplankton dynamics in two subtropical temporarily open/closed estuaries, South Africa. Mar Biol 148: 1307-1324

Kouassi E, Pagano M, Saint-Jean L, Sorbe JC (2006) Diel vertical migrations and feeding behavior of the mysid Rhopalophthalmus africana (Crustacea: Mysidacea) in a tropical lagoon (Ebrié, Côte d'Ivoire). Estuar Coast Shelf Sci 67:355-368

Lehtiniemi M, Kijunen M, Jones RI (2009) Winter food utiliza- tion by sympatric mysids in the Baltic Sea, studied by combined gut content and stable isotope analysis. Mar Biol 156:619-628

> Lehtiniemi M, Nordström H (2008) Feeding differences among common littoral mysids, Neomysis integer, Praunus flexuosus and $P$. inermis. Hydrobiologia 614: 309-320

Lindén E, Kuosa H (2004) Effects of grazing and excretion by pelagic mysids (Mysis spp.) on the size structure and biomass of the phytoplankton community. Hydrobiologia 514: $73-78$

Mauchline J (1980) The biology of mysids and euphausiids. In: Blaxter JHS, Russel FS, Yonge M (eds) Advances in marine biology, Vol 18. Academic Press, London

Mees J, Jones MB (1997) The hyperbenthos. In: Ansell AD, Gibson RN, Barnes M (eds) Oceanography and marine biology: an annual review, Vol 35. UCL Press, London, p 221-255

> Nozais C, Perissinotto R, Mundree S (2001) Annual cycle of microalgal biomass in a South African temporarily-open estuary: nutrient versus light limitation. Mar Ecol Prog Ser 223:39-48

> Parnell AC, Inger R, Bearhop S, Jackson AL (2010) Source partitioning using stable isotopes: coping with too much variation. PLoS ONE 5:e9672

Peterson BJ, Fry B (1987) Stable isotopes in ecosystem studies. Annu Rev Ecol Syst 18:293-320

Phillips DL, Eldridge PM (2006) Estimating the timing of diet shifts using stable isotopes. Oecologia 147:195-203

Post DM (2002) Using stable isotopes to estimate trophic position models methods and assumptions. Ecology 83: 703-718

Riera P, Richard P (1996) Isotopic determination of food sources of Crassostrea gigas along a trophic gradient in the estuarine bay of Marennes-Oléron. Estuar Coast Shelf Sci 42:347-360

Rolff C (1998) Stable isotope studies of contaminant and material transport in Baltic pelagic food-webs. $\mathrm{PhD}$ thesis, University of Stockholm, Sweden

Rolff C, Broman D, Näf C, Zebühr Y (1993) Potential biomagnifications of $\mathrm{PCDD} / \mathrm{Fs}$ - new possibilities for quantitative assessment using stable isotope trophic position. Chemosphere 27:461-468

Smit AJ, Brearley A, Hyndes GA, Lavery PS, Walker DI (2005) Carbon and nitrogen stable isotope analysis of an Amphibolis griffithii seagrass bed. Estuar Coast Shelf Sci 65: $545-556$

Suzuki KW, Kasai A, Isoda T, Nakayama K, Tanaka M (2008) Distinctive stable isotope ratios in important zooplankton species in relation to estuarine salinity gradients: potential tracer of fish migration. Estuar Coast Shelf Sci 78:541-550

Tackx MLM, Herman PJM, Gasparini S, Irigoien X, Billiones R, Daro MH (2003) Selective feeding of Eurytemora affinis (Copepoda, Calanoida) in temperate estuaries: model and field observations. Estuar Coast Shelf Sci 56:305-311

Viherluoto M, Viitasalo M (2001) Effect of light on the feeding rates of pelagic and littoral mysid shrimps: a trade-off between feeding success and predation avoidance. Exp Mar Biol Ecol 261:237-244

Viherluoto M, Kuosa H, Flinkman J, Viitasalo M (2000) Food utilization of pelagic mysids, Mysis mixta and M. relicta, during their growing season in the northern Baltic Sea. Mar Biol 136:553-559

- Vilas C, Drake P, Fockedey N (2008) Feeding preferences of estuarine mysids Neomysis integer and Rhopalophthalmus tartessicus in a temperate estuary (Guadalquivir Estuary, SW Spain). Estuar Coast Shelf Sci 77:345-356 
Whitfield AK, Taylor RH (2009) A review of the importance of freshwater inflow to the future conservation of Lake St. Lucia. Aquat Conserv Mar Freshw Ecosyst 19: 838-848

- Wilhelm FM, Hamann J, Burns CW (2002) Mysid predation on amphipods and Daphnia in a shallow coastal lake: prey selection and effects of macrophytes. Can J Fish Aquat Sci 59:1901-1907

Editorial responsibility: Edward Durbin, Narragansett, Rhode Island, USA
Winkler G, Martineau C, Dodson JJ, Vincent WF, Johnson LE (2007) Trophic dynamics of two sympatric mysid species in an estuarine transition zone. Mar Ecol Prog Ser 332: 171-187

Wooldridge TH (1999) Estuarine zooplankton community structure and dynamics. In: Allanson BR, Baird D (eds) Estuaries of South Africa. Cambridge University Press, Cambridge, p 141-166

Submitted: May 21, 2010; Accepted: August 31, 2010 Proofs received from author(s): October 12, 2010 